\title{
Biochemistry in Assessing the Inflammatory Response of the Respiratory System Due to Experimental Exposure to Glass Fibres
}

\author{
BIANCA DOMOKOS-HANCU ${ }^{1 *}$, MILENA ADINA MAN"1*, ANTIGONA CARMEN TROFOR2*, CARMEN MONICA POP1, \\ CRISTINA MARIA GAVRILESCU², ELENA COJ OCARU², ANDREI CERNOMAZ², ANDREI LESAN, CRISTIAN BOERESCU³, \\ ROXANA-MIHAELA BARBU², FLORINA POPESCU ${ }^{4}$ \\ IIuliu Hatieganu University of Medicine and Pharmacy, Pneumology Department, 8 Victor Babes Str., 400012, Cluj-Napoca, \\ Romania \\ ${ }^{2}$ Grigore T. Popa University of Medicine and Pharmacy, 16 Universitatii Str., 700115, lasi, Romania \\ 3EPSMA Établissement Public de Sante mentale Aube CMP / HJ Troyes Franc \\ ${ }^{4}$ Victor Babes University of Medicine and Pharmacy, 2 Eftimie Murgu Sq., 300041, Timisoara, Romania
}

\begin{abstract}
Given the structural resemblances between glass fiber and asbestos, it is important to understand the mechanisms through which exposure to glass fibers may affect the respiratory system. To study the effect of glass fiber on rat lung through intratracheal exposure, considering the subject's weight variation, together with haematological parameters, C-reactive protein (CRP), total number of lymphocytes, and IL8 concentration in bronchoalveolar lavage. We performed an intratracheal instillation study on four groups of 8 randomly selected Wistar rats, by administering 3 different doses of glass fiber. The hematocrit value was an indirect indicator of chronic hypoxemia; leukocytes and the C-reactive protein assessed systemic inflammation, and total number of lymphocytes and IL8 concentration in bronchoalveolar lavage fluid determined the lung's inflammatory response. Weight variation evaluated in all 8 measurements revealed no statistically significant changes ( $p=0.768$ ). The decrease in mean blood leukocytes was interpreted in relation with the glass fiber dose, with a statistically significant difference between the study groups $(p=0.003)$. Statistically significant differences were found in the CRP values, with dose correlations $(p<0.001)$. The bronchoalveolar lavage fluid showed increased levels of IL-8 $(p<0.05)$, and decrease of lymphocytes $(p<0.001)$ in correlation with the administered glass fiber dose. The inflammatory response following exposure to glass fibers in rats is correlated with administrated glass fiber dose. The alterations described as a result of intratracheal glass fiber instillation could predict the effects which occupational exposure to glass fiber may produce in humans.
\end{abstract}

Keywords: glass fiber, intratracheal instillation, animal models, occupational exposure

The exposure to noxious inhaled particles can lead to pathological changes in the respiratory tract. Most often these triggers lead to an inflammatory response which can initiate the development of sub-chronic or chronic pulmonary diseases [1]. Industries continue to develop and use various types of manmade vitreous fibers [2,3]. Glass fiber is largely used nowadays in many industrial fields: civil engineering, industrial engineering, electrical engineering, electronics and transportation. Given the structural resemblances between glass fiber and asbestos, an important goal is to understand the mechanisms through which exposure to glass fibers may affect the respiratory system (in order to implement preventive measures in different occupational exposure environments). Rodents have proved to be suitable surrogates, closely resembling people, in replicating lung diseases associated with asbestos exposure, subsequently extrapolated to other types of fiber. Despite important anatomical and physiological differences between rodents and humans, studies of chronic inhalation are considered to be the golden standard in testing the fiber pathogenicity [4]. The structure of glass fiber resembles that of asbestos. Asbestos exposure in humans is associated with severe diseases (mesothelioma, lung cancer, and fibrosis) only after a long latency period [5]. There are numerous unanswered questions resulting from this resemblance, taking into account the extremely widespread use of glass fiber nowadays, as well as the uncertainty regarding the effects glass fiber exposure has on the respiratory system. The most accurate model capable of predicting the possible chronic effects glass fiber exposure might haveon the respiratory system is represented by the subchronic exposure through instillation of glass fiber using animal models. The continuing development of a large number of synthetic fibers poses a real challenge for toxicologists. The International Agency for Research on Cancer (IARC) classifies glass fiber as potentially carcinogenic $[6,7]$. The studies on chronic exposure through inhalation have evidenced an increased incidence of tumors and lesions associated with the exposure dose. Fiber size and persistence have been identified as a determining factor of carcinogenesis. Long, thin fibers were associated with increased tumor incidence [8-11]. Most biologically relevant studies were performed on rodents - rats and hamsters. Due to technical limitations, the studies carried out in the past are not relevant. Exposure by intratracheal instillation, a method that avoids the upper airways, is consistent with the exposure of humans. Persistent inflammation has been reported in animal exposure model using asbestos and silica (materials with high toxicity) [12]. Cellular changes include the influx of proinflammatory cells (neutrophils, macrophages), cellular proliferation and apoptosis. It has been shown that severe inflammation is responsible for damage of epithelial cells and peri-bronchovascular edema and edema of the alveolar septal interstitium as well as edema in the alveolar lumen. 
The parameters that can be used for quantifying the lung inflammation include the number of inflammatoryl proliferating and apoptotic cells as well as the edema of the surface area and the damaged epithelium and endothelium [13]. The primary objective of our study is to evaluate the lung and systemic inflammation secondary to intratracheal instillation of fiber glass in rats.

\section{Experimental part}

We performed a glass fiber intratracheal instillation study on rats, by administering 3 different doses of glass fiber, the main objectives being to identify their effects on the lungs, the assessment of the magnitude of the postexposure effects in connection with the administered dose, at the end of the exposure period compared to a control group. We decided on a subchronic glass fiber instillation study because this type of exposure would best predict the effects of occupational exposure to glass fiber. The study was conducted with the approval of the ethics committee of the luliu Hatieganu University of Medicine and Pharmacy in Cluj Napoca, in accordance with the requirements of the European Convention for the protection of vertebrates used for experimental purposes.

\section{Material}

Animals: female Wistar rats weighing between 150 $250 \mathrm{~g}$ were used. The animals were kept in standard laboratory conditions. They were given food and water ad libitum [14-19]. The age of the animals at baseline was 910 weeks. During the non-exposure period the rats were kept in groups of 8 in polycarbonate cages. The room in which they were kept had air conditioning and environmental temperature was maintained at $+22^{\circ} \% 2^{\circ}$ C. During the study, they were subjected to 12 hours of artificial light and 12 hours of darkness [20]. Four groups of 8 randomly selected W istar rats were included in this study. Wistar rats are recommended for studies of subchronic or chronic exposure to fibers to determine their effects on the lungs as they are an accurate model of occupational exposure [21].

\section{Method}

The animals were divided into 3 test groups and a control group. The 3 test groups were exposed to different doses of glass fiber. The preparation of fibers consisted of grinding them by centrifugation for $35 \mathrm{~min}$ at $400 \mathrm{rpm}$. After preparation, fiber length and diameter were analyzed using optical microscopy. The chemical composition of the type of glass fiber used in this study is $65 \% \mathrm{SiO} 2,4 \%$ Al2O3, 8.5\% Na2O, 14\% CaO, 3\% MgO, 5\% B2O2, $0.5 \%$ Fe03. After preparing the test fiber, the 3 doses to be administered were measured on an electronic scale: 6 $\mathrm{mg}$ of glass fiber for group 1, $10 \mathrm{mg}$ of glass fiber for group 2 and $12 \mathrm{mg}$ of glass fiber for group 3 . In this study the test dose for each animal was administered in saline to facilitate distribution in the lungs. Saline solution is the most frequently used vehicle because it was shown it does not cause lesions. It is important for the vehicle to be free of endotoxins as they may cause secondary pulmonary inflammation and injury and can result in false positives. The dosage was selected because it was reported that exposure by intratracheal instillation of fibers in $5-20 \mathrm{mg}$ doses causes lung damage. The above general considerations have been taken into account in conducting this study [22, 23]. In group I, animals were marked 1-8 and then exposed to $6 \mathrm{mg}$ of glass fiber $/ 0.2 \mathrm{~mL}$ saline by intratracheal instillation, 5 days per week, for 10 weeks. In group II animals were marked 9-16 and exposed to $10 \mathrm{mg}$ of glass fiber $/ 0.2 \mathrm{~mL}$ saline by intratracheal instillation, 5 days per week, for 10 weeks. In group III, animals were marked 16-24 and exposed to $12 \mathrm{mg}$ glass fiber $/ 0.2 \mathrm{~mL}$ saline, 5 days a week, for 10 weeks. In the control group, animals were marked $25-32$ and $0.2 \mathrm{~mL}$ saline were instilled intratracheally, 5 days a week, for 10 weeks. We investigated the effects caused by subchronic exposure to glass fiber by intratracheal instillation and determined a number of biochemical and serological hematological parameters, by bronchoalveolar lavage and also by histopathological exam. The rats were clinically examined daily in terms of morbidity and mortality. They were weighed for 10 weeks. Eight weight measurements of the animals were performed at the beginning of the study (in week 1 and then 2, 3, 4, 6, 8 weeks after the study was initiated, as well as at the end of the study, in week 10). Hematocrit values were analyzed as an indirect indicator of chronic hypoxemia. The existence of a systemic inflammatory syndrome was evaluated by determining leukocytes and the C-reactive protein. A cytological examination of the bronchoalveolar lavage fluid was also performed and the total number of lymphocytes and IL8 concentration in the resulting supernatantwere determined in order to evaluate the inflammatory response in the lung. The blood was collected from the retrobulbar sinus, at the end of the exposure period, i.e. the end of week 10. We performed a full blood count (leukocytes, lymphocytes, granulocytes, and haematocrit), in all 4 groups ( 3 exposed groups and the control group) and the C-reactive protein was determined. The blood was then centrifuged at 1,500 rpm for 3 minutes. The separated serum was used for the determination of the CRP. Blood cell count parameters were determined by DIATRON haematology analysers. One week after the end of the exposure period all animals were euthanized. Following euthanasia, the lungs were removed together with the trachea. The lavage was performed by using $2 \times 5 \mathrm{~mL}$ saline, without performing a massage, the liquid was collected in special vacutainers, and its volume recorded. It was stored in an ice container prior to being processed. Cell concentration was determined and then centrifugation was performed at $1.500 \mathrm{rpm}$ for $10 \mathrm{~min}$. About $2 \mathrm{~mL}$ of supernatant was removed and stored at -70 $C$. The histopathological examination was performed at the end of the exposure period and multilevel biopsies were performed (trachea, main bronchia, upper lobe, cardial lobe and lower right lobe) using both HE and SR staining. The section of lower right lobe was stained with Sirius red to highlight weather collagen fiber deposition occurred. For the histopathological exam the tissue samples were placed in fixing solution and the samples were processed using the parafine inclusion technique, and then stained with haematoxylin-eosin (good differentiation between the cell types) and Sirius red (color selective way of the collagen fibers). For the statistical analysis Sigma Plot 12.0 software was used. Shapiro-Wilks normality test was applied. For the variables with normal distribution of analysis of variance (ANOVA) on Ranks test was used to determine the mean values and the standard deviation. For comparing the test groups versus control the Holm-Sidak method was used and for the analysis of the different correlations Pearson Product Moment Correlation test was performed for the normal distributed variables and Spearmen test for the variables with abnormal distribution.

\section{Results and discussions}

Weight variation in groups 1,2,3,4 was evaluated in all 8 measurements (fig. 1). We administered an ANOVA on Ranks test and average weight values per week in the 


\begin{tabular}{|c|l|l|l|l|}
\hline $\begin{array}{c}\text { Weight } \\
\text { (mean values) } \\
\text { (grams) }\end{array}$ & Group 1 & Group 2 & Group 3 & Control group \\
\hline Week 1 & $230 \pm 17.8$ & $224.50 \pm 27.3$ & $229.75 \pm 24.5$ & $209 \pm 29.7$ \\
\hline Week 2 & $229 \pm 18.0$ & $225.75 \pm 27.5$ & $229.37 \pm 24.5$ & $209 \pm 29.7$ \\
\hline Week 4 & $228.62 \pm 17.7$ & $225.12 \pm 27.2$ & $227.12 \pm 25.1$ & $209.8 \pm 28.8$ \\
\hline Week 6 & $228.25 \pm 17.5$ & $224 \pm 26.7$ & $225.62 \pm 26.0$ & $211 \pm 28.9$ \\
\hline Week 8 & $227.37 \pm 18.2$ & $223.50 \pm 26.8$ & $222.87 \pm 25.8$ & $211.7 \pm 28.4$ \\
\hline Week 10 & $225.25 \pm 17.5$ & $222.12 \pm 26.3$ & $220.12 \pm 25.2$ & $212.1 \pm 28.7$ \\
\hline
\end{tabular}

Table 1

WEIGHT- MEAN VALUES AND STANDARD DEVIATION

\begin{tabular}{|c|l|l|l|l|}
\hline $\begin{array}{l}\text { Haematological } \\
\text { parameters }\end{array}$ & Group 1 & Group 2 & Group 3 & Control group \\
\hline WBC & $6.32 \pm 1.9$ & $7.59 \pm 1.8$ & $4.37 \pm 1.03$ & $7.7 \pm 2.17$ \\
\hline Lymphocytes(\%) & $61.8 \pm 4.7$ & $50.4 \pm 4.6$ & $44.6 \pm 3.0$ & $65.3 \pm 4.7$ \\
\hline Granulocytes(\%) & $34.2 \pm 6.2$ & $43.3 \pm 6.3$ & $37.3 \pm 7.1$ & $28.8 \pm 2.0$ \\
\hline Haematocrit (\%) & $46.7 \pm 4.0$ & $49.6 \pm 2.6$ & $45.86 \pm 8.8$ & $50.49 \pm 1.0$ \\
\hline
\end{tabular}

study groups were determined, as shown in table 1. No statistically significant changes were found in the study groups $(p=0.768)$. The Spearman test was used to determine the correlation between body weight changes and the administered dose in the study groups, without identifying a statistically significant correlation, the weight not being influenced by the administered glass fiber dose. The mean and standard deviation of hematological parameters obtained by applying the ANOVA teston Ranks are shown in table 2. A Kruskal-Wallis test was used to compare the study groups, highlighting a statistically significant difference between the study groups $(p=0.003)$ and a decrease in mean blood leukocytes in relation with the administered dose of glass fiber. The C-reactive protein (CRP) was determined in all 4 groups, the normal CRP value being $0.00-0.30 \mathrm{mg} / \mathrm{dL}$. For a statistical analysis of the C-reactive protein values in the study groups, a oneway repeated measures ANOVA test was applied and we obtained the mean CRP values (table 3 ) and the standard deviation. To assess the systemic inflammatory status, the C-reactive protein was determined, its values being elevated in all groups that were studied as compared to the control group, with statistically significant differences that correlate with the administered dose $(p<0.001)$. To evaluate the inflammatory status, we determined the total number of lymphocytes and interleukin (IL-8) concentrations in the bronchoalveolar lavage fluid. Interleukin (IL-8) concentrations in the bronchoalveolar lavage are shown in figure 2.

By analyzing the results, we observe values that are above the normal upper limit $(16.6 \mathrm{pg} / \mathrm{mL})$ in 7 subjects from group 1 (87.5\%), all subjects in group 2 and $3(100 \%)$ and 3 subjects in the control group (37.5\%). A statistical comparison of concentrations of interleukin (IL-8) in the

Table 3

MEAN VALUES CRP STANDARD DEVIATION, STANDARD ERROR

\begin{tabular}{|l|l|l|l|}
\hline Group & Mean value CRP & $\begin{array}{l}\text { Standard } \\
\text { deviation }\end{array}$ & $\begin{array}{l}\text { Standard } \\
\text { error }\end{array}$ \\
\hline $\mathbf{1}$ & 0.321 & 0.0264 & 0.00934 \\
\hline $\mathbf{3}$ & 0.338 & 0.0255 & 0.00796 \\
\hline Control & 0.238 & 0.0233 & 0.00789 \\
\hline
\end{tabular}

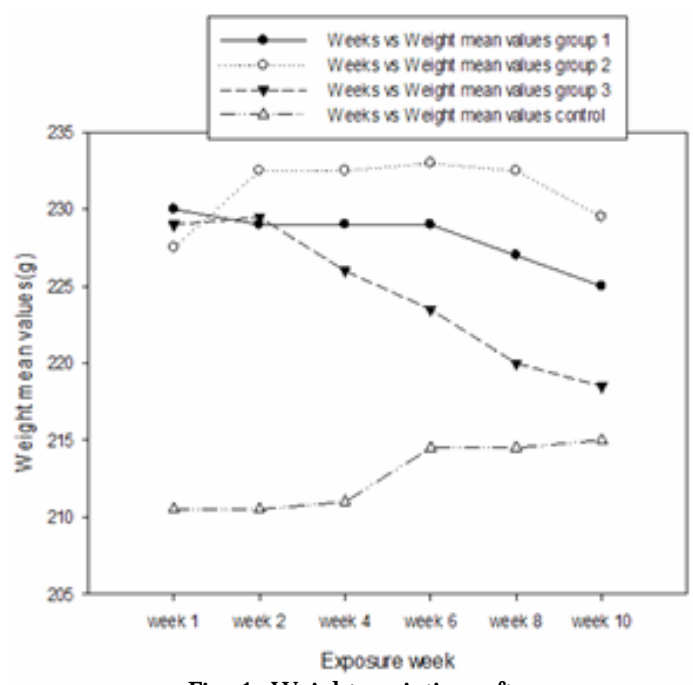

Fig. 1. Weight variation after exposure

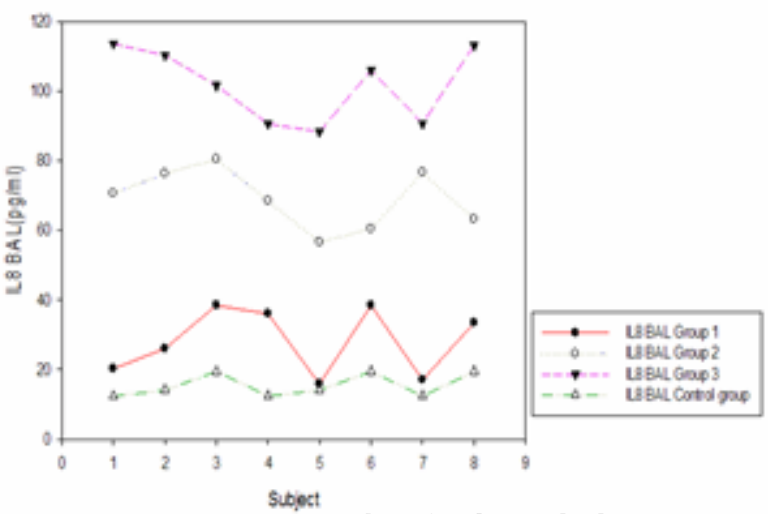

Fig. 2. BAL IL8 values for the studied groups

lavage was performed by applying the Kruskal-Wallis test, yielding the mean values and standard deviations, as follows: $28.15 \pm 9.5$ in group $1 ; 169.0 \pm 8.4$ in group 2; $101.78 \pm 10.6$ in group 3 ; and $15.3 \pm 10.6$ in the control group. There was a statistically significant difference between the study groups $(p<0.001)$. The Holm-Sidak test was used to compare the groups which were administered three different doses of glass fiber with the control group, also showing a statistically significant difference $(p<0.05)$. After analyzing these results, we concluded that the values of IL-8 in the bronchoalveolar lavage correlate with the administered glass fiber dose. The average values of IL-8 in the lavage according to the administered dose of glass fiber are shown in figure 3 . In order to assess the 


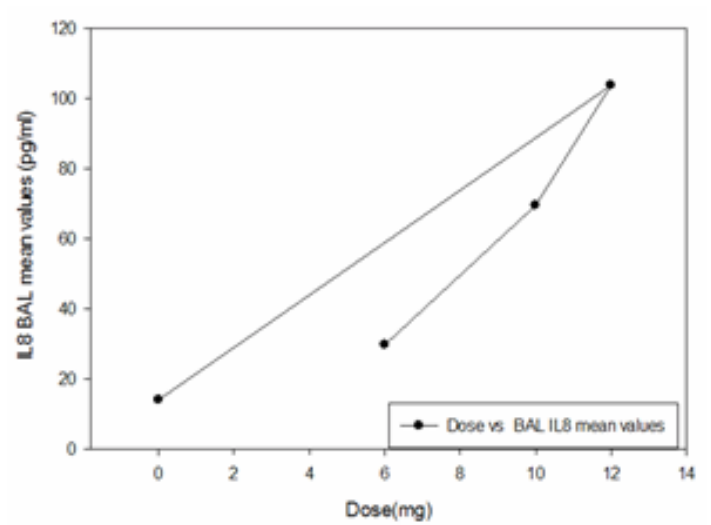

Fig. 3. BAL IL8 mean values vs fibre glass dose

inflammatory status, we determined the total number of lymphocytes in the lavage fluid. A one-way ANOVA test was applied and the average values and the standard deviation of the lymphocytes in the lavage were: $1700 \pm 177.2$ in group $1 ; 802 \pm 78.3$ in group $2 ;$ and $292 \pm 34.2$ in group 3. The control group showed no lymphocytes in the lavage fluid. The Holm-Sidak test was used for a comparison of the 3 groups, which showed a statistically significant difference between the mean values of lymphocytes in the lavage fluid $(p<0.001)$.

We notice an inversely proportional relationship with the administered glass fiber dose, which may be explained by their recruitment to the lung parenchyma. The mean value of the lymphocytes in the lavage cell according to the dose of glass fiber that was administered are show $n$ in figure 4. The relationship betw een IL-8values in the lavage and the lymphocyte count in the lavage was determined using the Spearman test, which showed increased concentration levels of IL-8according to the dose in the study groups and a decrease of lavage lymphocytes counts depending on the administered dose.

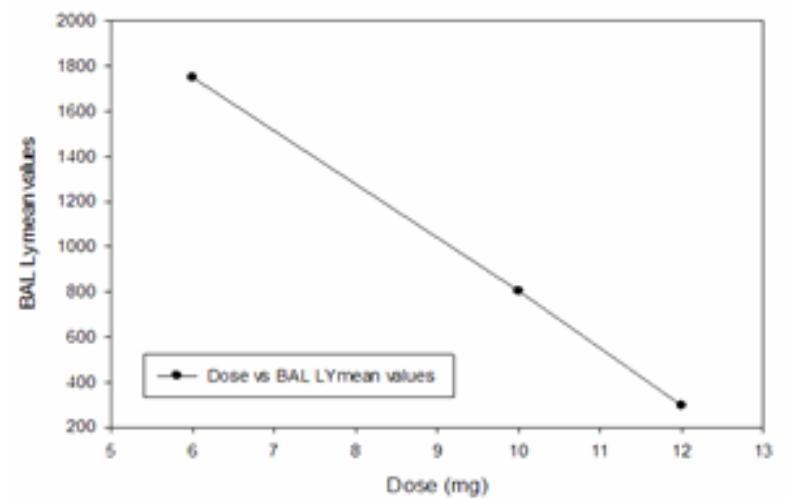

Fig. 4. BAL Lymphocite mean values versus fibre glass dose

The histopathological examination showed peribronchiolar lymphoid follicle hyperplasia, lymphohyistiocitary, neutrophilic and eosinophilic perivascularitis, descquamative alveolitis, and emphysema. We evaluated alveolar reepithelialization, pulmonary microgranulomas, collagen deposition in the bronchoalveolar junction, collagen deposition in the lung, macrophage cumulation in the bronchoalveolar junction and macrophage cumulation in the lamina propria. Each lesion was graded from 0-5 (from 0-no alteration to 5-severe alteration). The maximum score was 30 and we interpretated score 010 points like slight inflammatory, medium inflammatory with score 11-20 points and severe inflammatory with score 21-30 points. The inflammatory lessions described for the first group were minimal, for the second group the inflammatory lessions were moderate with discrete collagen proliferation and discrete fibrosis (total score ranged between 11-20 point) and accumulation of eosinophils in the lung which is more likely secondary to an allergic mechanism. For the third group we observe the most severe lessions with extended lung fibrosis, emphysema, ephitelization and the described inflammatory lessions were massive (total score 21-30 points) with collagen depossition, pulmonary and pleural fibrosis and lung emphysema and for the controll group the exam did not show any lessions.

The published data resulting from epidemiological and experimental studies in vivo or in vitro have limited value in predicting the effects that exposure to mineral fibers has on health. The pulmonary effects of particle exposure and severity of fiber-induced pathology depend on exposure time and concentration as well as on particle characteristics such as chemical composition, size, structure, dose, route of exposure and surface composition $[13,24,25]$. A multidisciplinary approach is needed to understand the exact mechanisms of mineral fibers toxicity. Other studies were performed to evaluate fiber toxicity such as the one performed by Friedrich Pott and co-workers, when they studied the toxicity of 19 different particles administered through intratracheal instillation to rats. The objective of their study was to determine to evaluate the Morrow-overload volumetric hypothesis and to determine lung cancer induction [26]. The results of their study initiated a lot of debate with two hypothesis: the one that supported the surface: hypothesis and other that considered the concept of volumetric overload as the leading mechanism of carcinogenesis [26]. At present it is not clear whether glass fiber, whose structure is similar to that of asbestos fiber, may cause asbestosis in humans. The bronchoalveolar lavage technique is widely used to evaluate pathogenetic mechanisms and the inflammatory response following exposure to glass fibers, it is a very valuable method in understanding the mechanisms of action and the influx of inflammatory cells. For most diseases there is a correlation between the type of asbestos that the subject is exposed to, the duration of exposure and its intensity. Fibrous lesions at pleural or parenchymal level are a nonspecific reaction following a chronic inflammatory process or trauma; asbestosis or diffuse interstitial fibrosis may progress after cessation of exposure and are considered as a risk factor for lung cancer by some authors [27], but not by other authors [28]. The biopersistence of glass fibers refers to their ability to persist in the lung and represents a critical factor in assessing the effects of fibers on lung, by taking their different properties into account: solubility and physiological clearance attissue level. Such properties of glass fibers as dose, size, chemical composition, electrical charge are other determinants of the ability of alveolar macrophages to engulf and remove efficiently fibers from the lungs, or to persist in the lungs and cause a chronic inflammatory response [29]. The design of a subchronic toxicity study requires three fundamental elements: the preparation and characterization of the fibers to be tested, the assessment of biopersistence in vivo and the determination of toxicological effects at gastrointestinal level [11, 27, 3032]. When characterizing fibers, we should take into account their chemical composition, crystallinity, distribution by size and concentration in the work environment ambient. The fibers to be tested should be respirable by rodents (rats, hamsters), a significant proportion of them being $>20$ micrometers in size, but also reflecting the characteristics of fibers that people are exposed to. Preparation and characterization of tested fibers is an essential first step in performing any study of 
inhalation/instillation on animals. The assessment of the toxicity of different fiber types often involves exposure of animals to the test material via inhalation. This method, although not an easy one, is preferred when testing various air pollutants, dust and fibers. The design and the development of an inhalation exposure system is difficult and expensive [33,34]. Intratracheal instillation has a number of advantages [35]. First of all, it enables the deployment of the precise exposure dose, that is of the dose of fibers placed in the lungs of each animal. Secondly, the technique is easier and reduces the risk of exposure of medical staff and lab technicians to these toxic materials. This method allows the study of several exposure doses over a short period of time and avoids contamination of the skin and fur of the testanimals. Intratracheal instillation allows the study of the effects of materials that are potentially toxic, respirable by humans but nonrespirable by rodents, such as long fibers and water-soluble compounds, and allows identification of the most toxic components of mixtures [36]. Despite these advantages, compared to inhalation and sensitization studies, the intratracheal instillation technique has several disadvantages. First of all, the way the tested material (fiber) is introduced is non-physiological and involves invasive manipulation. Secondly, the distribution of the particles may differ from the distribution of the material deposited in the lung by inhalation [37, 38], and the respiratory tract is shunted through this method, therefore the effects of the test material at this level [nasal cavity, oral cavity, pharynx, and larynx) cannot be assessed. Intratracheal instillation has been used in testing the pulmonary toxicity of various mineral powders, silica, low soluble material, quart, coal, and protein allergens [3942]. Many of these studies showed similarities in the biological response after exposure to the test material, irrespective of the method of administration. In vivo testing of biopersistence can be achieved by performing a separate, short duration ( 5 days) toxicity study on rodents or through a subchronic intratracheal inhalation/instillation study by including a subgroup on which the fibers will be tested after 5 days, at the end of the exposure period and at the end of the study. The persistence of the fibers in the lung was also estimated by using computer programs and various in vitro methods, but these methods are currently insufficiently standardized. The toxicological effects of exposure are yet to be determined, the recommended exposure time being of at least 1 month, preferably 3 months, inhalation or intratracheal administration being preferred. A subchronic study usually involves 2 or 3 differentexposure doses, the required concentration of one dose being of at least 150 fibers $/ \mathrm{cm}^{3}$, while its length should be $>20$ micrometers. The key parameters that should be monitored include: lung weight, bronchoalveolar lavage analysis, cell proliferation, histopathological examination, presence or absence of fibrosis [43-46]. The available information resulting from toxicity studies on different types of respirable fibers which are biopersistent in the lung suggests that they may also cause pulmonary diseases in humans: persistent inflammatory reaction, cell proliferation, pulmonary fibrosis and lung tumors. Several sub-chronic and chronic studies of asbestos toxicity have been conducted, the resulting information being correlated with their effects in humans. Pulmonary lesions induced by asbestos fibers cause a variety of effects both in humans and in animal models: non-neoplastic pleural changes, pleural effusion, parietal pleural fibrosis, asbestosis, lung carcinoma, malignant mesothelioma both in the pleura and the peritoneum, gastrointestinal carcinoma [11, 27, 30-32]. The inflammatory and immunological reaction in the lung and pleura may increase the toxicity of inhaled fibers, causing lung fibrosis. Moreover, the persistent inflammatory response contributes to the oxidative stress as well as the genetic and epigenetic changes associated with carcinogenicity. The inflammatory mediators secreted by macrophages following exposure to fibers were determined through several studies, and include eicosanoids (substances derived from membrane phospholipids and derivatives of polyunsaturated fatty acids having 20 carbon atoms), various cytokines, and chemokines.[46] Oxidative stress is considered to be the central mechanism in the production of pro-inflammatory mediators [47], through the activation of the nuclear transcription factor and the TNFá, ICAM-1 and COX2 genes. While determining signaling pathways, we can also determine the concentration of the released mediators: IL8, TNF, and IL1b.

The high dose exposure is associated with significantly increased pulmonary inflammation (large numbers of infiltrating macrophages, formation of granulomas, collagen deposition in alveolar septa, and fibrosis) and the lesions correlated with dose exposure. The pathogenesis of fibrosis is complex, may be specific for different agent and is poorly understood [48].

\section{Conclusions}

The mechanism through which glass fiber inhalation determines lung damage in humans is not thoroughly clear but it is commonly accepted that fiber pathogenicity depends on their ability to be inhaled and their persistence in the lung. Chronic inhalation exposure studies have shown an increased incidence of lesions associated with the exposure dose on animal models. The alterations described as a result of the study of intratracheal glass fiber instillation on the rats could predict the effects which occupational exposure to glass fiber may produce in humans.

Acknowledgements: We thanks to Dr. Septimiu Toader from Biobase of Iuliu Hatieganu University of Medicine and Pharmacy, Cluj-Napoca, and to Prof. Cornel Catoi - USAMV Cluj-Napoca - Morphopathology Department.

\section{References}

1.BRANDENBERGER, C., OCHS, M., MÜHLFELD, C., Part Fiber Toxicol, 12, 2015, p. 35.

2.MALAKOUTI, J., KOOHPAEI, A., JANG, S.A., DEHGHAN-NASIRI, M., Arch Hyg Sci, 4, 2015, p. 114-122.

3.MORARIU, S.I., DUCEAC, L.D., LUCA, A.C., POPESCU, F., PAVEL, L., GAVRILESCU, Rev. Chim.(Bucharest), 69, no. 2018, p 2278-2282.

4.SYKES, S.E., MORGAN, A., MOORES, S.R., DAVISON, W., BECK, J., HOLMES, A., Environ Health Perspect, 51, 1983, p. 267-273.

5 .***U.S. Department Of Health And Human Services, Public Health Service Agency for Toxic Substances and Disease Registry (ATSDR) Division of Toxicology ToxFAQs. Atlanta, Georgia: Public Health Statement for Synthetic Vitreous Fibers, 2004. (Accessed February 15, 2017, at site <https://www.atsdr.cdc.gov/toxfaqs/tfacts161.pdf>)

6.***World Health Organization International Agency for Research on Cancer. IARC Monograph on the evaluation of carcinogenic risk of chemicals to humans. Lyon, France: Man made vitreous fibers. IARC monographs, IARC Press, 81, 2002. (Accessed February 15, 2017, at site <https://monographs.iarc.fr/ENG/Monographs/vol81/mono81. $\mathrm{pdf}>$ ).

7.***Silica, Some Silicates, Coal Dust and para-Aramid Fibrils. Lyon, France, IARC monographs, 68, 1997, p. 1-506. (Accessed February 15, 2017, at site <http://monographs.iarc.fr/ ENG/Monographs/vol68/ mono68.pdf>).

8.BUNN, W.B. 3RD, BENDER, J.R., HESTERBERG, T.W., CHASE, G.R., KONZEN, J.L., J Occup Med, 35, 1993, p. 101-113. 
9.HESTERBERG, T.W., MIILLER, W.C., THEVENAZ, P., ANDERSON, R., Ann Occup Hyg, 39, 1995, p. 637-653.

10.HESTERBERG, T.W., AXTEN, C., MCCONNELL, E.E., HART, G.A., MIILLER, W., CHEVALIER, J., EVERITT, J., THEVENAZ, P., OBERDORSTER, G., Inhal Toxicol, 11, 1999, p. 747-784.

11.MCCONNELL, E.E., AXTEN, C., HESTERBERG, T.W., CHEVALIER, J., MIILLER, W.C., EVERITT, J., OBERDÖRSTER, G., CHASE, G.R., THEVENAZ, P., KOTIN, P., Inhal Toxicol, 11, 1999, p. 785-835.

12.MORIMOTO, Y., IZUMI, H., YOSHIURA, Y., TOMONAGA, T., OYABU, T., MYOJO, T., KAWAI, K., YATERA, K., SHIMADA, M., KUBO, M., J Nanopart Res, 17, 2015, p. 442.

13.TURCI, F., PAVAN, C., LEINARDI, R., TOMATIS, M., PASTERO, L., GARRY, D., ANGUISSOLA, S., LISON, D., FUBINI, B., Part Fiber Toxicol, 13, 2016, p. 32.

14. ${ }^{* * *}$ Animal Welfare Branch, NSW Department of Primary Industries, A.R.R.P Guideline 20 - Guidelines for the Housing of Rats in Scientific Institutions. Sydney NSW, Australia: Annual review - Guideline, 20, 2010, p. 1-79. (Accessed February 15, 2017, at site < http:// www.animalethics.org.au/_data/assets/pdf_file/0014/222512/housingrats-scientific-institutions. $\overline{p d f}>$ ).

15.***The European Convention for the Protection of Vertebrate Animals Used for Experimental and Other Scientific Purposes (European Treaty Series - No. 123). Guideline for acommodation and care of animals, 5, 1986, p. 18-24.

16.GALANI, R., DUCONSEILLE, E., BILDSTEIN, O., CASSEL, J.C., Physiol Behav, 74, 2001, p. 1-4.

17.LAWLER, M., Comfortable Quarters for Rats in Research Institutions. Comfortable quarters for Laboratory Animals $9^{\text {th }} \mathrm{Ed}$. Washington, DC, Animal Welfare Institute, Issue 9, 2002, p. 26-32.

18.GALEF, B.G. JR, SORGE, R.E., J Appl Anim Welf Sci 3, 2000, p. 279292.

19.HURST, J.L., BARNARD, C.J ., NEVISON, C.M., WEST, C.D., Anim Welf, 6, 1997, p. 329-347.

20.MCEACHRON, D.L., TUMAS, K., BLANK, K.J ., PRYSTOWSKY, M.B., Pharmacol Biochem Behav, 51, 1995, p. 947-952.

21.VU, V., BARRETT, J.R., ROYCROFT, J., SCHUMAN, L., DANKOVIC, D., BARON, P., MARTONEN, T., PEPELKO, W., LAl, D., Regul Toxicol Pharmacol, 24, 1996, p. 202-212.

22.HUBBS, A.F., PORTER, D.W., Inhal Toxicol, 6, 2005, p. 109-117.

23.LEMAIRE, I., NADEAU, D., DUNNIGAN, J., MASSÉ, S., Eviron Res, 36, 1985, p. 314-326.

24.ARMSTEAD, A.L., MINARCHICK, V.C., PORTER, D.W., NURKIEWICZ, T.R., LI, B., PLOSONE 10, 2015, p. 1371.

25.GREIM, H., UTELL, M., MAXIM, L.D., NIEBO, R., Inhal Toxicol, 26, 2014, p. 789-810.

26.BORM, P., CASSEE, F.R., OBERDÖRSTER, G., Part Fiber Toxicol, 12, 2015, p. 1-10.

27.COHEN, R.A., PATEL, A., GREEN, F.H., Semin Respir Crit Care Med, 29, 2008, p. 651-661.

28.NELSON, H.H., KELSEY, K.T., Oncogene, 21, 2002, p. 7284-7288.

29.NGUEA, H., DE REYDELLET, A., LE FAOU, A., ZAIOU, M., RIHN, B., Crit Rev Toxicol, 38, 2008, p. 675-695.
30HESTERBERG, T.W., MIILLER, W.C., MCCONNELL, E.E., CHEVALIER, J., HADLEY, J.G., BERNSTEIN, D.M., THEVENAZ, P., ANDERSON, R., Fundam Appl Toxicol, 20, 1993, p. 464-476.

31.MCCONNELL, E.E., HALL, L., ADKINS, B., Inhal Toxicol, 3, 1991, p. 323-337.

32.MAST, R.W., MCCONNELL, E.E., ANDERSON, R., CHEVALIER, J ., KOTIN, P., BERNSTEIN, D.M., THEVENAX, P., GLASS, L.R., MILLER, W.C., HESTERBERG, T.W., Inhal Toxicol, 7, 1995, p. 425-467.

33.SAITO, H., OJ IMA, J., TAKAHASHI, H., IWASAKI, T., HISANAGA, N., ARITO, H., Ind Health, 38, 2000, p. 323-326.

34.OBERDÖRSTER, G., COX, C., GELEIN, R., Exp Lung Res, 23, 1997, p. 17-34.

35.BRAIN, J.D., KNUDSON, D.E., SOROKIN, S.P., DAVIS, M.A., Environ Res, 11, 1976, p. 13-33.

36.DRISCOLL, K.E., COSTA, D.L., HATCH, G., HENDERSON, R., OBERDÖRSTER, G., SALEM, H., SCHLESINGER, R.B., Toxicol SCi, 55, 2000, p. 24-35.

37.NITU, F.M., OLTEANU, M., STREBA, C.T., JIMBOREAN, G., POSTOLACHE, P., MAN, M.A., TROFOR, A.-C., NEMES, R.O., DRAGONU, L., OLTEANU, M., Romanian Journal of Morphology \& Embryology, 58(2), 2017, p. 385-392.

38.MAN M.A., MAN S.C., MOTOC N.S., POP C.M., TROFOR A.-C., Romanian J ournal of Morphology \& Embryology, 58(2), 2017, p.627-634. 39.HENDERSON, R.F., DRISCOLL, K.E., HARKEMA, J.R., LINDENSCHMIDT, R.C., CHANG, I.Y., MAPLES, K.R., BARR, E.B., Fundam Appl Toxicol, 24, 1995, p. 183-197.

40.DRISCOLL, K.E., LINDENSCHMIDT, R.C., MAURER, J.K., PERKINS, L., PERKINS, M., HIGGINS, J., Toxicol Appl Pharmacol, 111, 1991, p. 201-210.

41.SARLO, K., FLETCHER, E.R., GAINES, W.G., RITS, H.L., Fundam Appl Toxicol, 39, 1997, p. 44-52.

42.HEINRICH, U., FUHST, R., RITTINGHAUSEN, S., CREUTZENBERG, O., BELLMANN, B., KOCH, W., Inhal Toxicol, 7, 1995, p. 533-556.

43.BERNSTEIN, D., CASTRANOVA, V., DONALDSON, K., FUBINI, B., HADLEY, J., HESTERBERG, T., KANE, A., LAI, D., MCCONNELL, E.E., MUHLE, H., Inhal Toxicol, 17, 2005, p. 497-537.

44.***U.S. Department of Health and Human Services, Agency for Toxic Substances and Disease Registry Division of Toxicology/Toxicology Information Branch (ATSDR). Atlanta, Georgia: Toxicological profiles for synthetic vitreous fibers, 2004, p. 1-322. (Accessed 15 February, 2017 at site <https://www.atsdr.cdc.gov/ToxProfiles/ tp161.pdf>).

45.***E.P.A. Scientific Advisory Panel Review. Health Effects Test Guidelines: OPPTS 870.8355 Combined Chronic Toxicity/Carcinogenicity Testing of Respirable Fibrous Particles. Washington, D.C., Health Effect Test Guidelines, 352, 2000, p. 1-13. (Accessed 15 February, 2017 at site <https://archive.epa.gov/scipoly/sap/meetings/web/ pdf/ isspaper_fbr.pdf $>$ ).

46.COJ O'CARU E., DUMITRIU I.L., GURZU B., COSTULEANU M., et al., Pneumologia, 58(1), 2009, p. 19-23.

47.TROFOR A., PETRIS O., TROFOR L., MAN M.A., FILIPEANU D., MIRON R. Rev.Chim.(Bucharest), 68, no.5, 2017, p.1002-1006 48.DOMOKOS-HANCU, B., MAN, M.A., HANCU, L., POP, C.M., Exp Lung Res, 40, 2014, p. 51-58.

Manuscript received:3.12.2018 